One egg from each of 33 sandpiper nests was collected on river islands in June and July. Fourteen eggs were from upstream of Edmonton, between Huggett and Devon, and 19 eggs were collected downstream from Edmonton between Vinca Bridge and Duvernay. The eggs were analyzed for residues of mercury in order to determine whether they could be used as indicators of mercury contamination sources located at Edmonton and/or downstream from that city. The mean and 05 per cent confidence interval of mercury residue levels in the 14 sandpiper eggs collected upstream from Edmonton were $0.09 \pm 0.03 \mathrm{ppm}$, as compared to $0.28 \pm 0.06 \mathrm{ppm}$ in the 19 sandpiper eggs collected downstream from tha city. The difference between thos levels is statistically significant an suggests a source of mercury contami nation at and/or downstream of Ed nonton. As the sandpiper's diet con sists of both terrestrial and aquati insects, the source of mercury pollu tion could not be further identified.

Although the Spotted Sandpipe does not appear to be a suitable ind cator of mercury contamination of th North Saskatchewan River, we ol tained a little more knowledge of $i$ food habits and its occurrence alon the river. The authors thank $\mathrm{Mr}$. I Kavanagh for his assistance with th identification of insects.

\title{
RECENT BIRD NOTES OF INTEREST FOR CHURCHILL, MANITOBA
}

by Ron Pittaway, 79 College Avenue, Ottawa, Ontario and Robert W. Nero, 546 Coventry Road, Winnipeg, Manitoba

Shortly after the publication of any local annotated list of birds a number of unusual birds are sure to appear in that locality. The following records include seven species not previously reported for Churchill, three of which are first records for Manitoba. Nearly all were obtained at Churchill at the time the recently published Birds of the Churchill region, Manitoba (Jehl and Smith, 1970) was in the hands of the printer. Judging by these additions, the Churchill region still offers ornithological surprises.

The senior author, who was at Churchill studying birds from May 5 to July 23, 1970, looks upon Churchill as the Point Pelee of the north. Birders who have spent any time at Point Pelee National Park on Lake Ontario will appreciate this remark, for the Point Pelee area attracts swarms of migrant birds in both spring and fall. Churchill is now a Mecca for birders who wish to see a lot of birds that are difficult to find anywhere in southern Canada. It also offers a chance to see birds that are rare on the continent.
Thanks are due the following pe sons for the use of their records for supporting observations: Dunc: R. Mackenzie, Churchill; Paul Mirs and others in his party, Queen's Ur versity, Kingston, Ontario; Dr. I Newton, Nature Conservancy, Edi burgh Scotland; Jerry Rosenbar Skokie, Illinois; and Mrs. Blanc Smith and Irwin H. Smith, Church.

\section{SPECIES LIST}

Harlequin Duck Histrionicus histrionicus

A male in breeding plumage $w$ observed by Pittaway and I. Newt on the Churchill River at Cape Mer July 11, 1970. The bird was stud closely for half an hour with binor lars and a Bausch and Lomb $15 \mathrm{x}$ zoom-telescope, at times as close 200 feet. It was observed swimmi in flight, and sitting on exposed roc It was last seen by Pittaway on $J$ 14.

This is the first record for Church As pointed out by Manning (19) 
8), Blakiston reported one from York actory, 140 miles southeast, prior to 863. There are seven additional Manioba records, including several specinens, from The Pas southward, from 898 to 1969 . Godfrey $(1966: 74)$ rearded it as a "rare transient" in cenral Canada.

Common Merganser Mergus merganser First recorded June 16, 1970 when Pittaway and P. Mirsky observed six ff Cape Merry.

Only previous record for Churchill, pair seen June 27, 1941 (Jehl and mith, 1970: 32).

ied-tailed Hawk Buteo jamaicensis

An adult was seen June 9, 1970 by ittaway and J. Rosenband about a nile north of Twin Lakes. The red upper surface of the tail could be seen asily as the bird glided and moved lowly from east to west.

Jehl and Smith (1970: 32-33) list ive previous occurrences.

\section{Whooping Crane Grus americana}

D. R. Mackenzie reported (pers. cores., November 30, 1970) : "On August 2th and 13th. 1969, I saw what I dentified as a Whooping Crane about ne-half mile east of the Rocket Launching Site. I watched it with 10 power field-glasses for about 10 or 15 ninutes. My attention had been drawn to it by three seagulls which were -wooping on it; it took off by jumping nto the air, not running on the ground, ts wing action was slow and strong, lark face and black wing tips, and egs trailing backwards. The second -ime I saw it it was flying in the same seneral area and heading south ...."

Jehl and Smith (1970: 36) give two ecords, a family group of three on October 1, 1953, and a group of hree on September 6, 1964. Its occurrence in recent years in southern Manitoba, where it might be expected, has been poorly documented and it must be considered a rare transient there. These northern records are far cast of the expected migration route from Wood Buffalo National Park to Texas. An unusual route or even another subarctic breeding locality should be considered.

Yellow Rail Coturnicops

noveboracensis

One was heard by Pittaway at La Pérouse Bay on June 24, 1970. This is three days earlier than previously recorded (Jehl and Smith, 1970: 37). Often as many as six could be heard calling at once at La Pérouse Bay and one was seen by Pittaway on June 28,1970 .

\section{Ruff Philomachus pugnax}

Pittaway observed an adult of undetermined sex arrive at the National Harbour Board pool nearest the townsite, along with Lesser Yellowlegs and Short-billed Dowitchers at 5:15 p.m., June 23, 1970. Although clearly an adult it was in molt and was closer to fall plumage than breeding plumage. He studied the bird closely with a $15 \times 60$ telescope while it was feeding, noting two rather large oval white patches at the base of the tail, a stout bill, yellowish at the base, orangeyellow legs, dark brown back and upper breast. A narrow wing stripe in flight and a broad black central stripe on the rump were also recorded. This bird was seen also by Blanche and $I$. H. Smith, and I. Newton. Pittaway had seen Ruffs on two previous occasions in Ontario; Dr. Newton was familiar with this species in England.

There is no previous record for Churchill or Manitoba. Godfrey (1966: 164) reports one collected at Fort Severn, Ontario on Hudson Bay, about 315 miles southeast of Churchill. The latter author regards this species as an "accidental visitor from Eurasia." However, Peakall (1965) suggests that it may breed in North America. Jones and Myres (1968: 21), reporting on a flock of four Ruffs observed in southern Alberta, May 15, 1967, felt it might be breeding in the Canadian north, "possibly even in one of the Prairie Provinces." Myres (pers. corres., 1968) later said he thought the subarctic area of northern Manitoba 
was a likely place to look for it as a possible breeding bird. Other records from adjacent areas include one collected at Regina, Saskatchewan, May 8, 1965 (Brazier, 1965), one seen at Saskatoon May 9-19,1970 (Roy, 1971), and one studied near Alberta, Minnesota, May 23, 1964 (Strubbe, 1964).

\section{Solitary Sandpiper Tringa solitaria}

So few late summer dates are available for this species it seems worthrecording that D. R. Mackenzie obtained one with a broken wing in midAugust, 1970 (pers. corres., 1970). It is regarded as uncommon to rare in the region (Jehl and Smith, 1970:41).

\section{Wilson's Phalarope Steganopus tricolor}

Pittaway observed two females and a male in the Harbour Board pools, May 30, 1970. Field marks could be checked easily by comparison with nearby Northern Phalaropes. The Wilson's Phalaropes remained there for at least two weeks. They were seen in the pools by D. R. Mackenzie, J. Rosenband, and a number of others including P. Mirsky.

On July 12, a single Wilson's Phalarope in fall plumage (male) was seen by I. Newton, P. Mirsky and Pittaway in a pool near the airport runway. Blanche Smith observed one with three Northerns in a pond near the runway on three occasions during the last two weeks of July.

There are no previous records of this prairie-nesting species for Churchill, other than a supposedly invalid nesting report for the early 1930's (see under Northern Phalarope, Jehl and Smith, 1970: 42).

\section{Ring-billed Gull Larus delawarensis}

Three adults were studied at close range with a telescope at the Harbour Board pools, June 19, 1970, by Pittaway. Size, yellowish-green leg color and ring on the bill were readily observed. Herring and Bonaparte's gulls were present for comparison. One was seen also on July 2 at Cape Merry.

Jehl and Smith $(1970: 51)$ give one previous record, one seen on June 14, 1968.
Black-headed Gull Larus ridibundus

British ornithologist Dr. Ian Newton observed an adult in breeding plumaga at the Fort Churchill garbage dump, July 23, 1970. Being completely familiar with this species in England he had little difficulty making the identification, noting a brown hood, red bill, a flash of white in the wings, and the slaty-colored underside of the primaries. His observation was discussed in detail with Pittaway.

This is the first record of this species for Manitoba. Regarded in Canada as a "rare visitor" from the Old World, it has not previously been reported west of Ontario (Godfrey, 1966: 183).

\section{Little Gull Larus minutus}

An adult in breeding plumage was seen with several Bonaparte's Gulls at the Harbour Board pools, July 20, 1970 , by Pittaway, Blanche and I. H. Smith, I. Newton and many others. Pittaway, who was familiar with this species in Ontario, noted its dark hood, dark red bill, slate-black wing linings and lack of white in the forewings. Alongside Bonaparte's Gulls it seemed a third smaller and had a much smaller head. At times it was studied as close as 20 feet. Although details are lost in the poor photograph that is available the smaller size is evident.

This is the first record of this old World immigrant for Manitoba. A male, apparently on territory in a colony of Bonaparte's Gulls, was collected on June 28, 1962, in northwestern Saskatchewan (Nero, 1963: 87). There are numerous records for the Atlantic coast and it occurs frequently in southern Ontario, where it has recently been found nesting (Godfrey, 1966: 185).

\section{Common Tern Sterna hirundo}

Pittaway observed one June 3, 1970 perched on a rock with a few Arctic Terns at the Harbour Board pools; all were in full breeding plumage. Usins a $15 \times 60$ zoom-telescope he recorder the larger tarsal length, longer bil coloured orange-red (instead of a dark blood red) with a black tip. Paler contour plumage and longer wings, ex. 
nding beyond the tail, were evident. ne was seen here on many occasions June and Pittaway was able to show to P. Mirsky.

Jehl and Smith (1970:53) reported ghtings, but none as well documented the above.

\section{lourning Dove Zenaidura macroura}

Pittaway and J. Rosenband saw one close range as it flew along the coast ear Paradox Creek, June 12, 1970. osenband had seen one a few days arlier.

There are six previous records cited J Jehl and Smith (1970:55), the last 1957.

\section{ank Swallow Riparia riparia}

Pittaway had a good look at one at he Harbour Board pools, June 13, 970 , noting the breast band, brown ack, and buzzy manner of flight. $\mathrm{He}$ aw one again later on the same day ver the water at the tip of Cape Merry.

Although not previously reported or Churchill, H. Hosford observed it the west on the Wolverine River in 966 (Jehl and Smith, 1970:60).

liff Swallow Petrochelidon pyrrhonota Pittaway and J. Rosenband saw one ying over the townsite, June 11, 1970. Jehl and Smith (1970:60) had no ecords but noted that "its occasional resence in Churchill is to be exected."

\section{Brown Thrasher Toxostoma rufum}

Pittaway and J. Rosenband found a male singing from the top of a power pole on Harbour Board property, June 2, 1970 .

Recorded at Churchill on three preious occasions (Jehl and Smith, 1970: 2).

\section{Yellowthroat Geothlypis trichus}

D. R. Mackenzie found an immature male (examined in the flesh by Nero) alive but with its tail and claws frozen nto the ice in a small pond surrounded by willows, November 11,1970 . It was rept alive until November 13.
Jerl and Smith (1970:67) reported several summer records, but with no indication of any breeding locally.

Pine Grosbeak Pinicola enucleator

D. R. Mackenzie reported that "one of a flight of five that was around here for about a week" was rescued from a Labrador dog on October 14, 1970 (pers. corres., 1970).

Recorded at Churchill to August 23 with the observation that "later records can be expected" (Jehl and Smith, 1970: 69).

\section{LITERATURE CITED}

Brazier, F. H. 1965. First Saskatchewan record of the Ruff. Blue Jay, $23: 120-121$.

Godfrey, W. E. 1966. The birds of Canada. Natl. Mus. Can. Bull. No. 203. Ottawa. $428 \mathrm{pp}$.

JehI, J. R., Jr., and B. A. Smith. 1970. Birds of the Churchill region, Manitoba. Spec. Publ. No. 1, Manitoba Museum of Man and Nature, Winnipeg. $87 \mathrm{pp}$.

Jones, B., and M. T. Myres, 1968. First record of Ruff for Alberta. Blue Jay, 26: 17-21.

Manning, T. H. 1952. Birds of the west James Bay and southern Hudson Bay coasts. Natl. Mus. Can. Bull. No. 125, Ottawa. $114 \mathrm{pp}$.

Nero, R. W. 1963. Birds of the Lake Athabasca region, Saskatchewan. Spec. Publ. No. 5, Saskatchewan Natural History Society, Regina. $143 \mathrm{pp}$.

Peakall, D. B. 1965. The status of the Ruff in North America. Wilson Bull., $77: 294-296$.

Roy, J. F. 1971. Second Saskatchewan record of the Ruff. Blue Jay, 29:11.

Strubbe, E. H. 1964. The Ruff. Loon, 36:53-55.

\section{NEST RECORDS SCHEME}

For the 1970 season 1476 nest record cards on 129 species were received from 68 Prairie Provinces and NWT contributors. Cards have been checked and entered in the master files. During the year the following cards were used: Tree Swallow (Maritime Blackbird (Royal Ontario Museum); Forest Ranger School); Brewer's Townsend's Solitaire, Lesser Yellowlegs and Indigo Bunting (University of Michigan).

Summary of 1970 contributors and cards may be obtained from the editor. Cards and instructions may be obtained from H. W. R. Copland, Coordinator Prairie Nest Record Scheme, Manitoba Museum of Man and Nature, 190 Rupert Ave., Winnipeg 2, Manitoba. 